\title{
Diurnal Cycle of Cloud System Migration over Sumatera Island
}

\author{
Namiko SAKURAI \\ Graduate School of Science and Technology, Kobe University, Kobe, Japan \\ Fumie MURATA \\ Research Institute for Human and Nature, Kyoto, Japan \\ Manabu D. YAMANAKA \\ Graduate School of Science and Technology, Kobe University, Kobe, Japan \\ Institute of Observational Research for Global Change, Japan Agency for Marine-Earth Science \\ and Technology, Yokohama, Japan*

\section{Shuichi MORI, Jun-Ichi HAMADA} \\ Institute of Observational Research for Global Change, Japan Agency for Marine-Earth Science \\ and Technology, Yokohama, Japan*
}

\section{Hiroyuki HASHIGUCHI}

\begin{abstract}
Research Institute for Sustainable Humanosphere, Kyoto University, Uji, Japan ${ }^{\dagger}$
\end{abstract}
\section{Yudi Iman TAUHID, Tien SRIBIMAWATI}

Agency for the Assessment and Application of Technology, Jakarta Pusat, Indonesia

and

\section{Budi SUHARDI}

Indonesian Meteorological and Geophysical Agency, Jakarta Pusat, Indonesia

(Manuscript received 12 March 2004, in final form 28 June 2005)

Corresponding author: Namiko Sakurai, Graduate School of Science and Technology, Kobe University, 1-1 Rokkodai, Kobe 657-8501, Japan.

E-mail: sakurai@ahs.scitec.kobe-u.ac.jp (C) 2005, Meteorological Society of Japan

* IORGC was reorganized from Frontier Observational Research System for Global Change on July 1, 2004.

$\dagger$ RISH was reorganized from Radio Science Center for Space and Atmosphere on April 1, 2004. 


\begin{abstract}
This paper describes a diurnal cycle in systematic cloud system migration observed with the GMS IR1 sensor over Sumatera (approximately 1,500 km in length) from May 2001 to April 2002. Convective clouds developed over mountainous areas in the afternoon, and migrated westward and/or eastward for several hundred kilometers $(\sim 500 \mathrm{~km})$ from midnight to morning. Westward migration occurred in almost every month except August over southernmost Sumatera Island. Eastward migration occurred when lower-tropospheric winds were westerly and/or when super cloud clusters moved eastward along the Intertropical Convergence Zone (ITCZ), which moves northward and southward with an annual cycle.
\end{abstract}

\section{Introduction}

Convective activities in the tropics play an important role in the global transport of water vapor and energy, and therefore influence the global climate. Convection is especially active over the Indonesia maritime continent (Ramage 1968), which consists of many islands of various sizes and is surrounded by the warmest sea waters in the world. Hierarchies of convective activities with various temporal and spatial scales range from local circulation to large-scale disturbance in the tropical oceans near Indonesia (Nakazawa 1988).

A diurnal cycle is dominant over tropical landmasses (Hendon and Woodberry 1993). Diurnal cycles of tropical convection in areas such as tropical Asia and the western Pacific have been widely studied using Geostationary Meteorological Satellite (GMS) black-body temperature data that correspond to the cloud-top temperature. Diurnal cycles of deep convection over land and sea show a distinct contrast. Convection over continents and large islands is most intense in late afternoon (around 19 LST). In contrast, convection over seas near continents and large islands is most intense in the morning (around 03 LST). Diurnal cycles over continents and large islands are likely forced by strong surface heating during the day, whereas diurnal cycles over adjacent maritime areas arise from interactions between sea-land breeze circulations and large-scale environmental flows (Murakami 1983; Nitta and Sekine 1994). Characteristics of diurnal variations vary seasonally. At Serpong, West Jawa, distinct diurnal variations of the mixed layer (up to $5 \mathrm{~km}$ in early afternoon) and winds (sealand breeze circulation) were observed using a UHF-band wind profiler (boundary layer radar).
Variations were especially pronounced during the dry season (Hashiguchi et al. 1995, 1996). Hadi et al. $(2000,2002)$ confirmed similar diurnal variations, and depicted cloud movements that accompanied sea-breeze intrusions.

The amplitude and peak time of cloud activity in a diurnal cycle are highly dependent on geographical (topographical) conditions. Diurnal cycles east of $150^{\circ} \mathrm{E}$ over active convection regions including the Intertropical Convergence Zone (ITCZ) and the South Pacific Convergence Zone (SPCZ) have smaller amplitudes than diurnal cycles over the maritime continent and peaks that appear in the morning and secondarily in the afternoon (Nitta and Sekine 1994). Analysis of surface rainfall and GMS data with high temporal-spatial resolutions has shown that convective activities and precipitation have late-night-early-morning maximum in windward mountain areas, basins and valleys, and coastal areas of tropical Asia. These maxima are most likely associated with terrain or terrain-induced local circulations, that is, mountain and land breezes (Ohsawa et al. 2001).

Nocturnal-phase propagation in such diurnal cycles has also been shown. Climatologies of diurnal cycles in convection, cloudiness, and surface temperature have revealed coherent diurnal convective variations propagating over water several hundred kilometers from the Indonesian Islands, the Bay of Bengal, southwestern Mexico, and west Africa. These propagations have been associated with gravity waves. The coherent diurnal variations around Indonesian islands were affected by sea-land breeze circulations (Yang and Slingo 2001). Nocturnal convection generated over the sea northwest Borneo (Kalimantan) moves farther offshore (west-northwestward), reaching its 
maximum in the early morning creating a squall line, which is caused by land breeze convergence with northeast monsoon flow (Houze et al. 1981; Johnson and Kriete 1982). Using a two-dimensional, non-hydrostatic, cloud-resolving numerical model, squall lines with solar-synchronized life cycles and their eastward migration caused nighttime maximum of precipitation over inland area of Indochina were simulated, and the squall lines were caused by mountain waves and cold air flows from the western mountains (Satomura 2000). An analysis of radar echo data confirmed similar phase propagation in leeward regions (Okumura et al. 2003). There are several different diurnal cycles over the Bay of Bengal. Cloud systems propagate from the coast to offshore. The land-water interface drives convection initiation and thereby affects the spatial distribution of convection (Zuidema 2003). Cloud systems propagate northward from the northern coast of New Guinea; these propagating cloud systems arise from low-level convergence between the large-scale flow and a land breeze (Liberti et al. 2001). Mapes et al. (2003a, b) and Warner et al. (2003) described observational and numerical studies of westward rainfall peak migration to offshore regions in the night time over northwestern South America. They suggested that cloud migration was caused by gravity waves emanating off of the land topography.

Such nocturnal-phase propagations also occur over regions other than the tropics. Cloud systems over the eastern Tibetan Plateau, for example, migrated eastward with a diurnal cycle that may have been related to wind fields at $500 \mathrm{hPa}$ (Asai et al. 1998). From North America precipitation data, Wallace (1975) found that the most frequent precipitation area in the warm season moved eastward from the lee of the Rockies during late-night hours. Riley et al. (1987) used higher resolution data to confirm a similar migration of precipitation maxima, while Meisner and Arkin (1987) used threehourly infrared satellite data over the eastern edge of the Rocky Mountains to document an eastward phase shift of the diurnal cycle. Wavelike systems in the free troposphere and/or the planetary boundary layer might contribute to the diurnal cycle of eastward migration (Carbone et al. 2002).

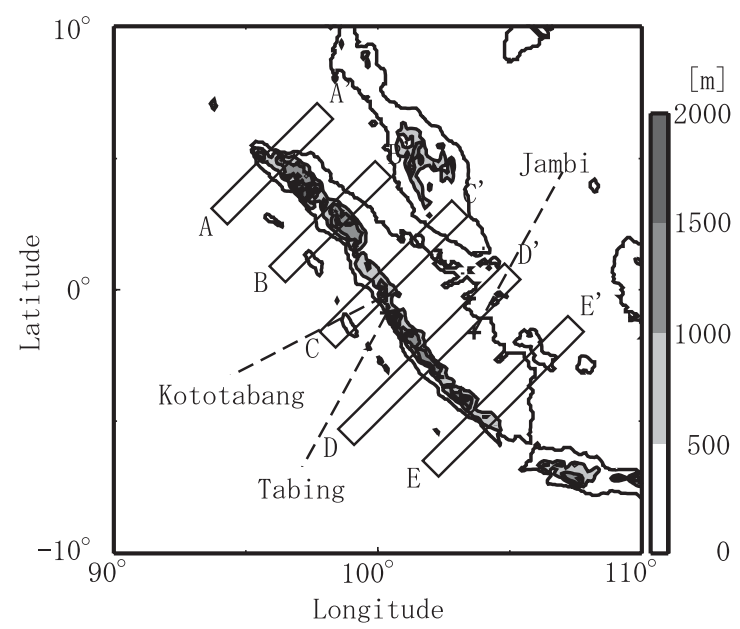

Fig. 1. Sumatera Island topography. Intensive observations took place at Tabing, Kototabang, and Jambi stations from 2001 to 2003. The diurnal cycle of cloud system migration was analyzed along five slices $\left(\mathrm{AA}^{\prime}\right.$ to $\left.\mathrm{EE}^{\prime}\right)$.

Although the diurnal cycle clearly dominates in the tropics, the cycle is not well understood because of sparse ground-based observations. The diurnal cycle over Sumatera Island in particular has been described only briefly. Sumatera Island stretches approximately $1,500 \mathrm{~km}$ from $6^{\circ} \mathrm{S}-6^{\circ} \mathrm{N}$ at the western end of Indonesia. Mountainous, volcanic areas of 2,000-3,800 m are found in western Sumatera, while plains are prevalent in eastern Sumatera (Fig. 1). The mountains form a barrier for flows and clouds from the Indian Ocean. The western slopes trap moisture from the Indian Ocean, creating greater rainfall amounts in the western mountains than in the eastern districts (Sakagami et al. 1990). Super cloud clusters showing intraseasonal variability propagate eastward along the Equator and receive transformations over Sumatera Island; this transformation contributes to the importance of Sumatera Island among the many islands of Indonesia (Nitta et al. 1992).

Since 1998 many observations in Indonesia have been carried out by cooperations of the Agency for Assessment and Application of Technology (BPPT), the Meteorological and Geophysical Agency (BMG), and the Institute of Aeronautics and Space (LAPAN) in Indone- 
sia and Kyoto University, Kobe University, and the Japan Agency for Marine-Earth Science and Technology (JAMSTEC) in Japan. Hamada et al. (2002) used data from operational rain gauges, and described geographical differences in Indonesian precipitation. A diurnal rainfall cycle dominated with the maximum precipitation around 15-21 LST during the rainy season at Bukittinggi, in the center of the mountainous districts (Hamada 2003). Precipitating clouds were characterized by a diurnal variation that peaked in the afternoon. The peak in stratiform clouds followed the peak in deep convective clouds, which corresponds to the life cycle of a mesoscale convective system (Renggono et al. 2001). However, diurnal variations in rainfall at Kototabang were suppressed when lower tropospheric westerly winds were strong (Murata et al. 2002), suggesting that most precipitation at Kototabang was caused by local circulations, not large-scale disturbances. A GPS receiving system that monitors precipitable water was installed at Kototabang in 2001. It has shown that water vapor is transported up to approximately $3 \mathrm{~km}$ by turbulent mixing as the boundary layer develops in the afternoon. Water vapor might also be transported horizontally by local circulations in the dry season (Wu et al. 2003). Extensive rawinsonde observations 2001-2002 at Tabing (on the west coast), Kototabang, and Jambi (on the eastern plain area) (Fig. 1), and precipitation radar (PR) data from the Tropical Rainfall Measuring Mission (TRMM) satellite have shown that a rainfall peak migrated from the southwestern coastline of Sumatera Island to inland and offshore regions during the day and night, respectively (Mori et al. 2004). It was suggested that the eastward migration until the late evening might be due to the background westerly wind in the lower troposphere, whereas the westward migration might arise from the generation of new convection over the windward side by self-replication and/or gravity wave mechanisms.

This paper uses GMS data to describe climatological features in the diurnal cycle of cloud system migration over Sumatera Island throughout one year. Unlike TRMM data, GMS data are continuous in space and time. Cloud systems develop in the afternoon along mountain ranges on Sumatera Island and then mi- grate toward both (west and east) coastlines for several hundred kilometers during night. Seasonal variations in the diurnal cycle are described before defining the mechanism. Section 2 includes data and observations. Section 3 details observational results in November 2001. Section 4 contains a statistical analysis of data from May 2001 to April 2002. Observational evidence that westward and eastward migrations appear under different conditions is discussed in Section 5. Section 6 contains the conclusions.

\section{Observation and data}

\subsection{Satellite data}

An earlier paper of our group (Mori et al. 2004) used precipitation data from TRMM. TRMM has a quasi-polar orbit that precluded recording continuous temporal variations at each local position. This paper analyzes cloudtop temperature from GMS; these data allow analyses of local temporal variations (including traces, day-to-day variations and seasonal differences in cloud system migration).

\section{1.a. Discrimination of deep convective clouds}

Cloud top temperature was analyzed from black body temperature $\left(T_{\mathrm{BB}}\right)$ on $0.1^{\circ} \times 0.1^{\circ}$ grid points derived from $0.05^{\circ} \times 0.05^{\circ}$ GMS IR1 grid points for one year (May 2001-April 2002). The temporal resolution was an hour. A threshold value of $T_{\mathrm{BB}}$ was specified to screen out ground temperatures and discriminate deep convective clouds.

The threshold value can dramatically alter the portrayal of diurnal variation of convective activity (Chen and Houze 1997). Generally, diurnal variations of convective activity evaluated using colder threshold temperatures exhibit maxima at earlier in the day (e.g., Minnis and Harrison 1984; Janowiak et al. 1994). Previous studies have used several threshold values, and the phase of convective activity often does not correspond to that of the rainfall. Nitta and Sekine (1994) showed that peak convective activity lagged peak precipitation by two hours for a threshold value of $250 \mathrm{~K}$. The index of convective activity can be defined so that diurnal variations of convective activity and rainfall have the same phase and peak simultaneously. Ohsawa et al. (2001) used 
$T_{\mathrm{BB}}$ from the IR1 channel and $T_{\mathrm{BB}}$ from the water vapor (WV) channel to show that $\Delta T_{\mathrm{BB}} \equiv T_{\mathrm{BB}}(\mathrm{IR} 1)-T_{\mathrm{BB}}(\mathrm{WV})<3 \mathrm{~K}$ correlates well with both intensive rainfall and the cloudtop temperature $T_{\mathrm{BB}}<230 \mathrm{~K}$. Therefore, the threshold value $T_{\mathrm{c}}=230 \mathrm{~K}$ was used in this study, following the example of other previous studies (e.g., Hendon and Woodberry 1993; Satomura 2000). In the present case, $230 \mathrm{~K}$ corresponds to air temperature near $11 \mathrm{~km}$.

An occurrence frequency $\alpha$ of deep cloud systems $\left(T_{\mathrm{BB}} \leq T_{\mathrm{c}}\right)$ at each pixel and time was calculated for a month as follows:

$\alpha \equiv \frac{\left(\text { The number of } T_{\mathrm{BB}}<T_{\mathrm{c}}\right)}{(\text { The total number of valid data for a month })} \times 100$,

which revealed how frequently convective clouds penetrated above $11 \mathrm{~km}$. A monthly value of $\alpha$ was not calculated if the number of missing data exceeded 4 for one month.

Equation (1) was also used to define the ITCZ around $100^{\circ} \mathrm{E}$, but a $T_{\mathrm{c}}$ of $270 \mathrm{~K}$ rather than $230 \mathrm{~K}$ was used. The goal was to define areas of extensive cloud cover as the ITCZ because the ITCZ is characterized by active convection. For this ITCZ analysis, an analysis period was changed from one month to five days. Around $100^{\circ} \mathrm{E}$ the ITCZ was present when $\alpha$ exceeded $50 \%$.

\section{1.b. Cross-section analysis over Sumatera Island}

As mentioned above, western Sumatera Island features mountainous districts and eastern Sumatera contains plains (see Fig. 1). Local winds reversed with a diurnal cycle due to sealand or mountain-valley breeze circulations may exist. These local winds are assumed to be perpendicular to coastlines or mountain ridges. Research has found that seasonal variations are inhomogeneous over Sumatera Island, which lies across the Equator, extending into both hemisphere (e.g., Hamada et al. 2002). Five cross-sections $\left(\mathrm{AA}^{\prime}, \mathrm{BB}^{\prime}, \mathrm{CC}^{\prime}, \mathrm{DD}^{\prime}\right.$ and $\mathrm{EE}^{\prime}$ in Fig. 1), that were approximately perpendicular to the coastlines and mountain ridge of Sumatera Island, were considered.

\subsection{Rawinsonde data}

BMG launches rawinsondes operationally at 11 stations in Indonesia, though not daily
(Okamoto et al. 2003). For example, at the Tabing station $\left(100.35^{\circ} \mathrm{E}, 0.88^{\circ} \mathrm{S}, 2 \mathrm{~m}\right.$ MSL) rawinsondes are usually launched at $0700 \mathrm{LST}$ $(\mathrm{UTC}=\mathrm{LST}-7)$ every other day.

Several Indonesian and Japanese institutions (see Section 1; also Mori et al. 2004) carried out intense rawinsonde observations during seven periods (May-June, August and November 2001, April and November 2002, July and November 2003) at three stations on Sumatera Island: Tabing (along the western coast), Kototabang $\left(100.32^{\circ} \mathrm{E}, 0.20^{\circ} \mathrm{S}, 865 \mathrm{~m}\right.$ $\mathrm{MSL}$, in the mountains), and Jambi $\left(103.64^{\circ} \mathrm{E}\right.$, $1.63^{\circ} \mathrm{S}, 26 \mathrm{~m} \mathrm{MSL}$, on the plains about $100 \mathrm{~km}$ inland from the east coast; see Fig. 1). Each intense observation period (IOP) lasted four weeks. Tabing and Kototabang are roughly located along the cross-section $\mathrm{CC}^{\prime}$ in Fig. 1. Jambi is near $\mathrm{DD}^{\prime}$. We employed the receiver and transmitters of a GPS-rawinsonde system (Vaisala RS-15GH) with meteorological balloons (TOTEX TA-1000 type for daytime, and TX-1000 type for night-time) at Kototabang and Jambi, and a radar tracking rawinsonde system (Meisei RS3-89A transmitters and a Weather Tronics receiver) at Tabing. Both rawinsonde systems recorded vertical profiles of temperature, relative humidity, pressure, and zonal and meridional winds at $100-\mathrm{m}$ resolutions.

Analyses in this study mainly used data observed in November 2001. This period corresponds to one of two rainy seasons (during March-May and September-November) over central Sumatera Island (Hamada 2003) that arise from the annual migration (north-south shift around the equator) of the ITCZ (Murakami and Matsumoto 1994; Okamoto et al. 2003). Rawinsondes were launched four times daily at around 0030, 0630, 1230, and 1830 LST during the first and fourth weeks, and eight times daily at around 0030, 0330, 0630, 0930, 1230, 1530, 1830, and 2130 LST in the second and third weeks at Kototabang and Jambi in November 2001.

\subsection{Equatorial atmosphere radar (EAR)}

The Equatorial Atmosphere Radar (EAR) is a VHF (47.0 MHz) Doppler radar with an active phased-array antenna system (peak output power of $100 \mathrm{~kW}$, approximately $110 \mathrm{~m}$ in diameter with 560 three-element Yagi anten- 
nas) that has operated at Kototabang since June 2001 (Fukao et al. 2003). It detects threedimensional (horizontal and vertical) atmospheric motions from $2-20 \mathrm{~km}$ during both clear and rainy conditions. Precipitation particle motions are also detected during rain. The EAR has a time resolution of approximately $90 \mathrm{~s}$ and a vertical resolution of approximately $150 \mathrm{~m}$. The time resolution of EAR is thus much finer than the time resolution of rawinsondes even in the intense observational periods, and it provides detailed time features in the diurnal cycle. In this paper, EAR data in November 2001 was used for the analysis.

\subsection{Objective analysis data}

The NCEP/NCAR objective reanalysis dataset provided by the US National Weather Service was used in this study. The spatial resolution and the analysis period are $2.5^{\circ} \times 2.5^{\circ}$ grid points and one year (May 2001-April 2002), respectively. The temporal resolution is 6 hours (0000, 0600, 1200, and 1800 UTC). The vertical resolution is 17 standard pressure levels from 1,000 to $10 \mathrm{hPa}$.

\section{Diurnal cycle observed in November 2001}

\subsection{Migrations of cloud systems}

Figure 2 shows a time-longitude cross-section of $T_{\mathrm{BB}}$ from GMS IR1 data over the Equator and zonal wind averaged from $2-4 \mathrm{~km}$ using rawinsonde data at Kototabang in November 2001. During this period, three super cloud clusters (marked with semi-circles) with time scales exceeding a few days passed over Sumatera Island. Zonal wind in the lower troposphere at Kototabang varied with the passage of the three super cloud clusters. From 3-10 November, a super cloud cluster moved eastward, and cloud clusters with the time scales shorter than a few days propagated westward. Between 11-18 November and 22-30 November, two other super cloud clusters passed eastward over Sumatera Island. Clusters with shorter time scales moved eastward east of $100^{\circ} \mathrm{E}$ over Sumatera Island on $4,5,7,12,19$, 25 , and 29 November.

The diurnal cycle of convective activity over Sumatera Island in November 2001 was analyzed. Figure 3 shows the horizontal distribution of occurrence frequency $\alpha$ for deep cloud systems in November 2001. Convection developed over and on the western side of the mountain districts of Sumatera Island in the afternoon (15 LST). Deep cloud systems were concentrated in the evening (18 LST) over western Sumatera Island. At night (21, 00, and 03 LST), the cloud systems split and migrated both westward and eastward. In the morning (06 and 09 LST), the systems were off both coastlines of Sumatera Island. It was found that such diurnal cycle of cloud system migration occurred systematically over Sumatera Island. Since Fig. 3 shows calculations for one month, actual cloud system migration on each day may be in two (opposite) directions or in one direction (as in Fig. 2).

Regional differences of cloud system migration with diurnal cycle over Sumatera Island were examined. Figure 4 shows time-longitude cross-sections of $\alpha$ along the five lines defined in subsection 2.1.b and shown in Fig. 1. Convection was especially active along $\mathrm{DD}^{\prime}$ and $\mathrm{EE}^{\prime} . \alpha$ peaked in the evening in mountainous areas at around $17 \mathrm{LST}$, except at $\mathrm{DD}^{\prime}$ and $\mathrm{EE}^{\prime}$, where the peaks appeared near 20 LST. Along $\mathrm{AA}^{\prime}$ and $\mathrm{BB}^{\prime}$, westward migration began just after the peak (17 LST), and eastward migration started around 23 LST. Along $\mathrm{CC}^{\prime}, \mathrm{DD}^{\prime}$, and $\mathrm{EE}^{\prime}$, westward and eastward migrations began almost simultaneously after the peak (17 LST in $\mathrm{CC}^{\prime}$ and $20 \mathrm{LST}$ in $\mathrm{DD}^{\prime}$ and $\mathrm{EE}^{\prime}$ ). Table 1 shows migratory velocities and distances for the cloud systems along each cross-section. Migration was calculated using least-squares techniques by tracing $\alpha$ peaks from their start in the mountainous area until they stopped or disappeared. Along $\mathrm{BB}^{\prime}$ and $\mathrm{DD}^{\prime}$, migratory velocities and distances for westward migration exceeded those for eastward migration, whereas along $\mathrm{AA}^{\prime}, \mathrm{CC}^{\prime}$, and $\mathrm{EE}^{\prime}$ westward migration values were smaller than eastward one. We found that eastward migratory distances along $\mathrm{AA}^{\prime}, \mathrm{BB}^{\prime}$ and $\mathrm{CC}^{\prime}(200-300 \mathrm{~km})$ are smaller than those along $\mathrm{DD}^{\prime}$ and $\mathrm{EE}^{\prime}(400-500 \mathrm{~km})$. It should be noted that Malay Peninsula exits in the eastward directions of the former three cross-sections, whereas only sea surface exists for the latter two cross-sections.

Analysis along $\mathrm{CC}^{\prime}$, which passes Kototabang, showed westward cloud system migration on seven days $(3,4,8,11,14,17$, and 18 November) and both westward and eastward 


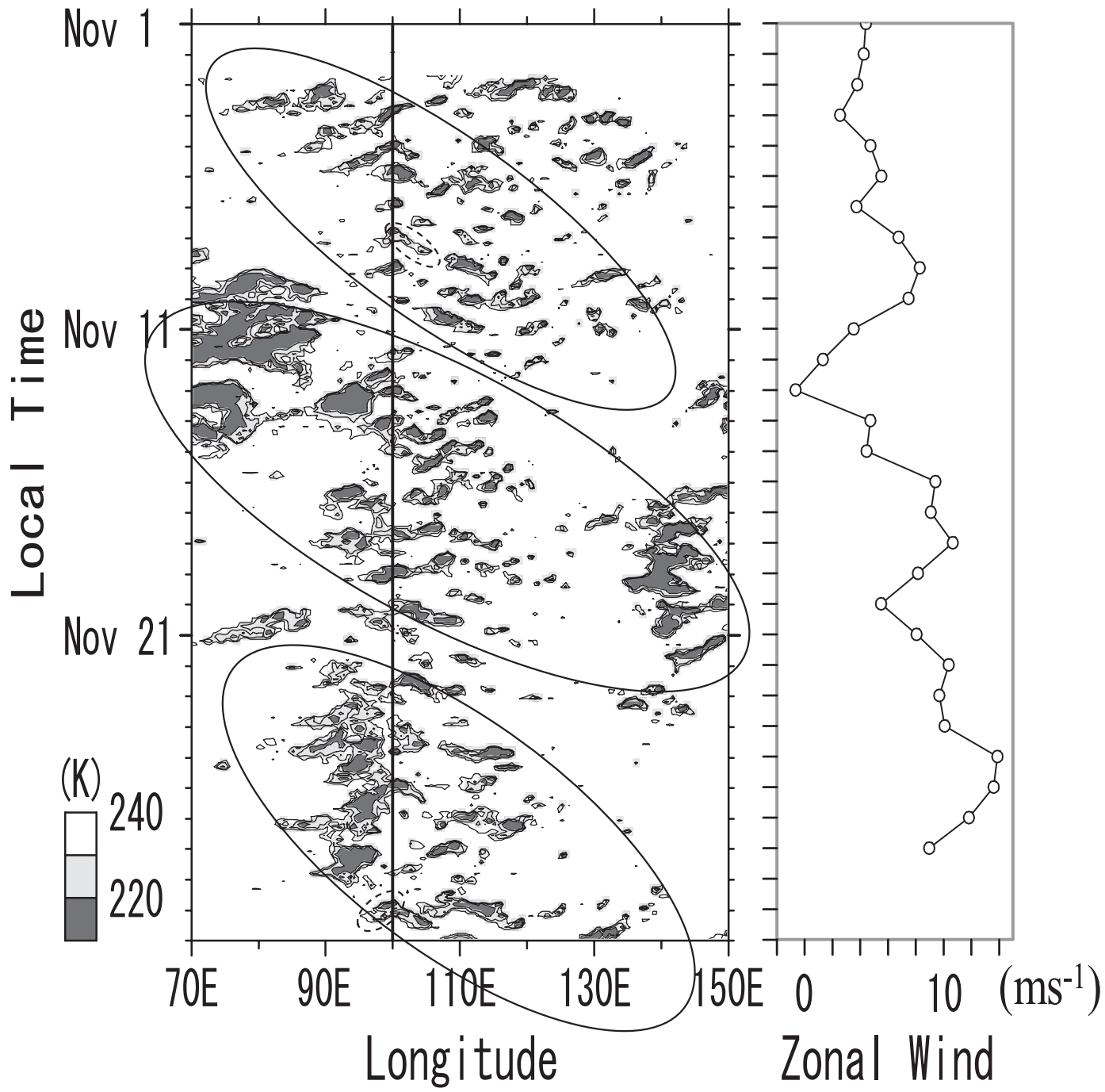

Fig. 2. Time-longitude cross-section on the Equator of $T_{\mathrm{BB}}$ (left panel, based on GMS IR1 data with a spatial resolution of $0.5^{\circ} \times 0.5^{\circ}$ ) and zonal wind averaged for $2-4 \mathrm{~km}$ altitudes (right panel, from rawinsonde data at Kototabang) in November 2001. The vertical solid line in the left panel indicates $100^{\circ} \mathrm{E}$, which corresponds to the location on the Equator of Sumatera's central mountain range. Three semi-circles indicate super cloud clusters passing over Sumatera Island during November 2001. Two dotted semi-cricles on 7 and 29 November in the left panel represent westward or eastward cloud system migration.

migrations on seven days $(5,6,12,13,19,22$, and 25 November). Similarly, along $\mathrm{DD}^{\prime}$ (near Jambi) westward migration occurred on fourteen days $(2,3,5,8,12,13,14,15,16,17,24$, 27,28 , and 29 November) and both westward and eastward migrations occurred on eight days (4, 6, 10, 11, 19, 21, 23, and 25 November). Along both lines, eastward migration alone was not observed in this analysis period.

\subsection{Comparisons with wind variations}

This subsection considers wind variations at larger and smaller scales during the same period as in the previous subsection. Figure 5 is a vertical-zonal cross-section of horizontal wind and relative humidity averaged for 12 UTC during November 2001 over the Equator. November is a rainy season in the central (equatorial) part of Sumatera (but not other parts of 

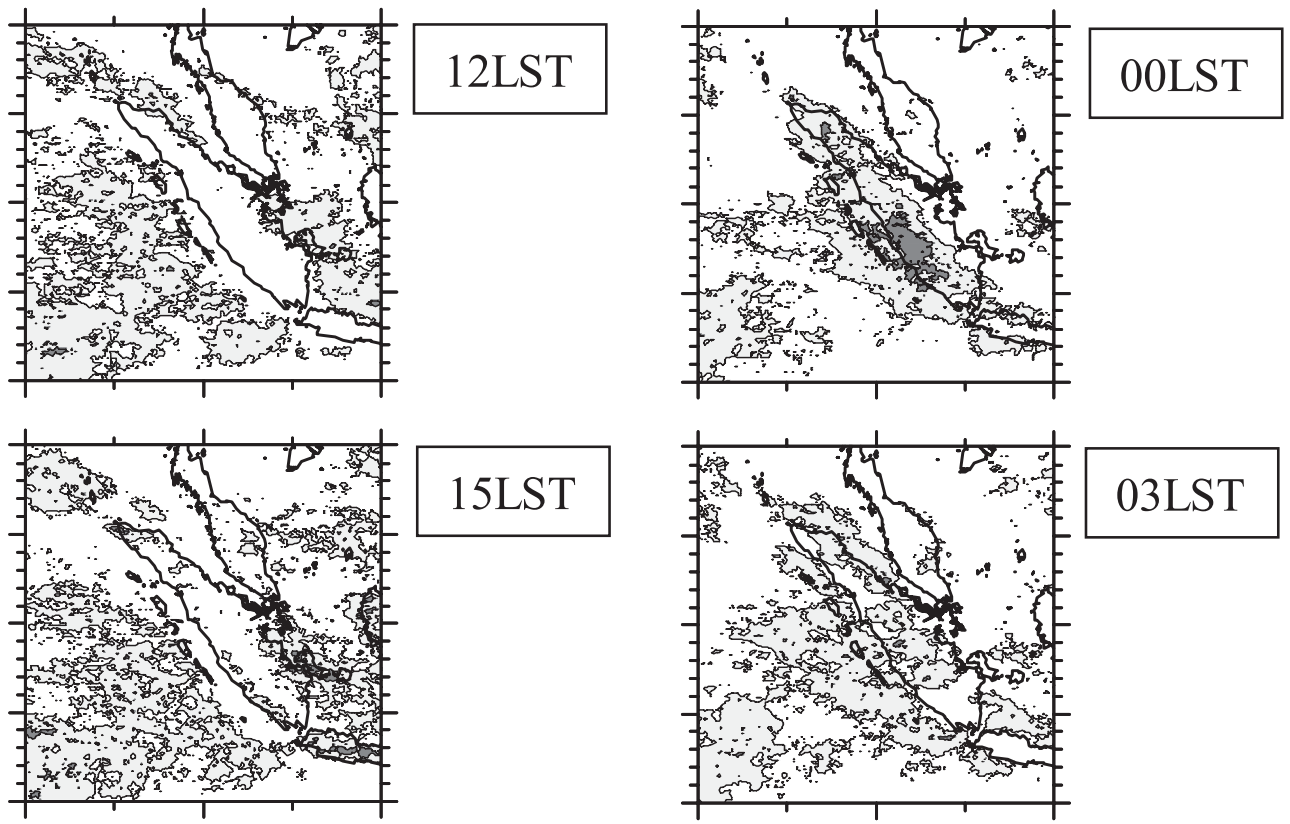

\section{$15 \mathrm{LST}$}

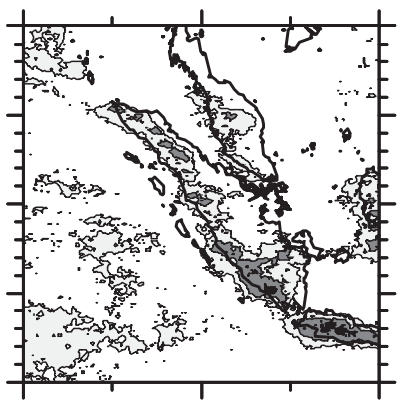

\section{LST}

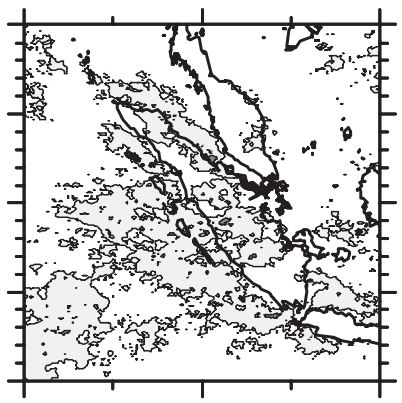

\section{LST}
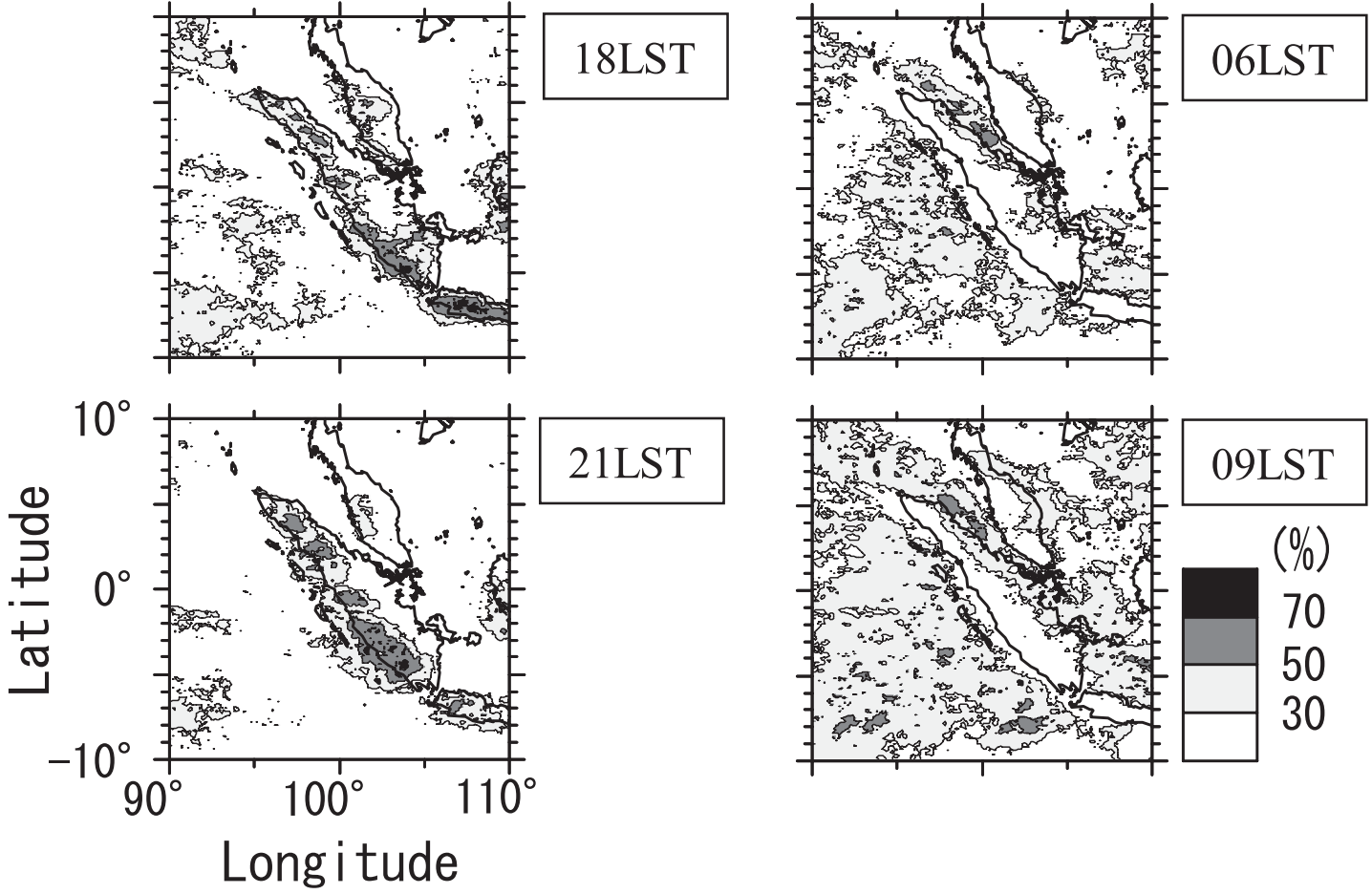

Fig. 3. Horizontal distributions of $\alpha$ for deep cloud systems (cloud-top temperature $\leq 230 \mathrm{~K}$ ) at each pixel and time every three hours over Sumatera Island and surroundings in November 2001. $\alpha$ is defined by Eq. (1), as presented in the text.

the island; see Hamada 2003), so relative humidity was high throughout the troposphere over the corresponding longitudinal region. The fact that humidity was especially high over land up to the upper troposphere meant that convection over land was active. At the Equator, westerly winds were present below $600 \mathrm{hPa}$, and easterly winds were found above $500 \mathrm{hPa}$. 

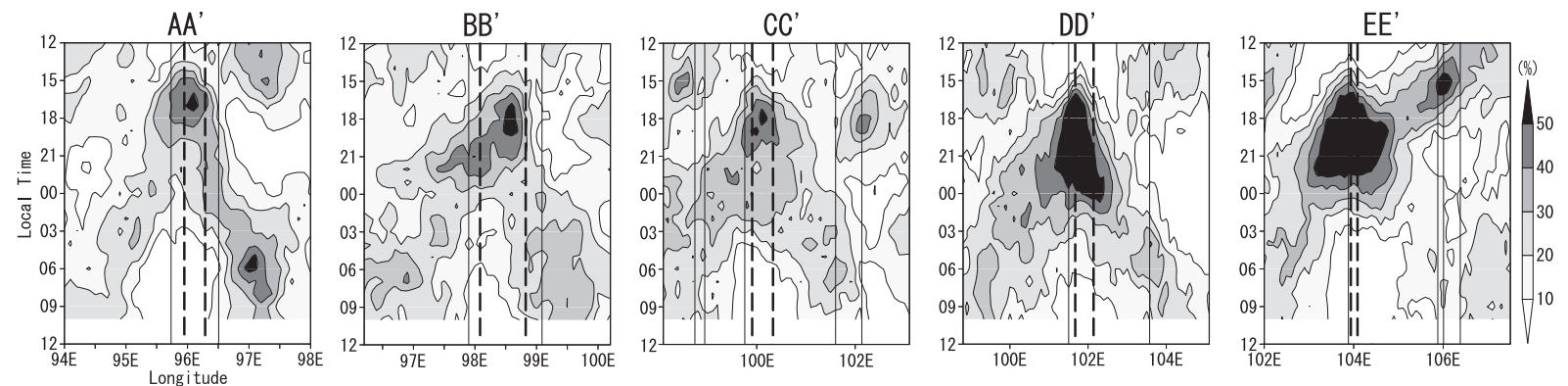

Fig. 4. Local time-longitude cross-sections of $\alpha$ for deep cloud systems (cloud-top temperature $\leq$ $230 \mathrm{~K}$ ) at each pixel along the five slices from $\mathrm{AA}^{\prime}$ to $\mathrm{EE}^{\prime}$ shown in Fig. 1 during November 2001. Vertical solid and broken lines represent the locations of coasts of Sumatera and other islands and 500 m MSL, respectively (see Fig. 1).

Table 1. Migratory distance and speed for deep cloud systems (cloud-top temperature $\leq 230 \mathrm{~K}$ ) along each cross-section over Sumatera Island in November 2001.

\begin{tabular}{|c|c|c|c|c|}
\hline & \multicolumn{2}{|c|}{ Westward migration } & \multicolumn{2}{c|}{ Eastward migration } \\
\hline & distance & speed & distance & speed \\
\hline & $(\mathrm{km})$ & $\left(\mathrm{ms}^{-1}\right)$ & $(\mathrm{km})$ & $\left(\mathrm{ms}^{-1}\right)$ \\
\hline $\mathrm{AA}^{\prime}$ & 199 & 3.5 & 202 & 3.5 \\
\hline $\mathrm{BB}^{\prime}$ & 362 & 5.9 & 202 & 3.1 \\
\hline $\mathrm{CC}^{\prime}$ & 240 & 4.8 & 279 & 6.0 \\
\hline $\mathrm{DD}^{\prime}$ & 492 & 9.1 & 431 & 8.6 \\
\hline $\mathrm{EE}^{\prime}$ & 289 & 6.2 & 483 & 10.3 \\
\hline
\end{tabular}

Figure 6 shows mean diurnal variations of zonal wind observed with EAR and rawinsondes from November 1-28 at Kototabang. The EAR data were averaged every 1 hour before taking 28-day mean. EAR and rawinsonde averages were very similar even though time resolution of rawinsonde data ( 6 hours) was much lower than that of EAR one (1 hour). There were westerly (easterly) winds below (above) $7 \mathrm{~km}$, and the westerly wind was weak (strong) around 13 LST (19 LST). Rawinsonde data could accurately express the characteristics of diurnal variations in zonal winds, at least for the purposes of this study. Background wind structures, with westerly (easterly) wind below (above) 6-7 km throughout the day, were also

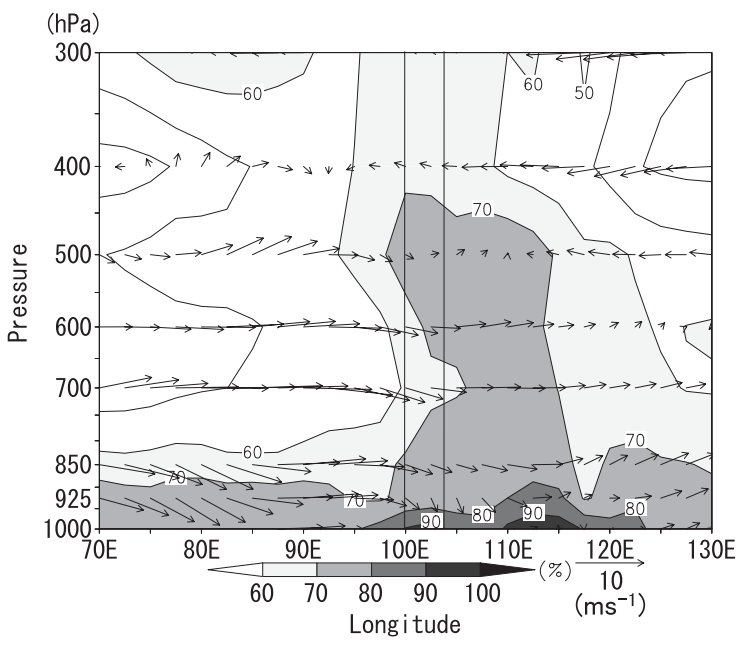

Fig. 5. Vertical-zonal cross-section averaged for horizontal wind (arrows; upward prepresents northward) and relative humidity (shaded areas exceed $60 \%$ ) on the Equator at 12 UTC (19 LST over Sumatera Island) in November 2001, based on Data from the NCEP/ NCAR objective reanalysis dataset were used. Solid lines represent the coasts of Sumatera Island.

confirmed by rawinsondes launched at Jambi from November 1-28, as shown in the mean vertical profiles of Fig. 7.

The relationship between cloud system passage and wind direction was investigated by separately analyzing wind averages for each cloud cluster migratory direction (determined 
(a)

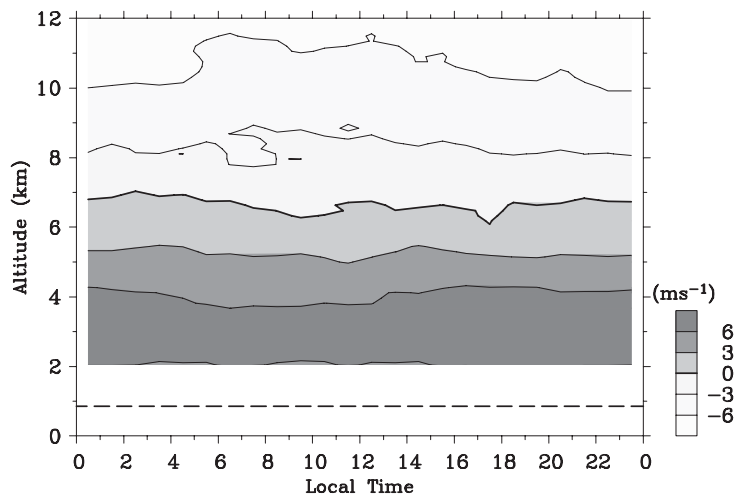

(b)

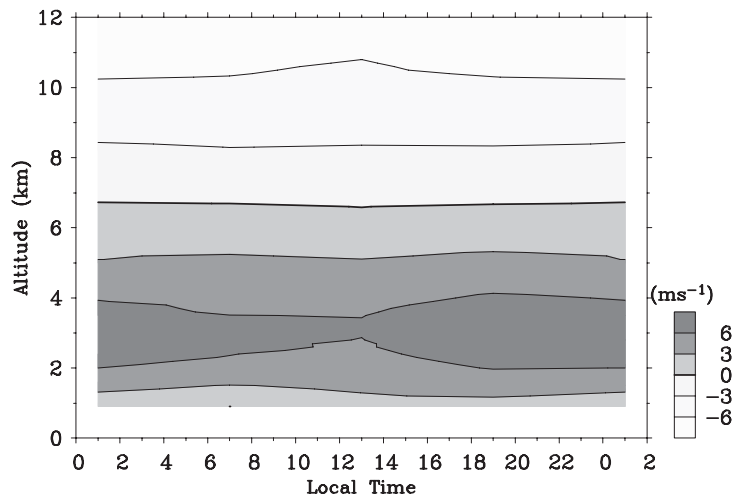

Fig. 6. Vertical-local time cross-sections of mean diurnal variation of zonal wind in November 2001 observed with (a) EAR and (b) rawinsondes at Kototabang. The broken line in (a) represents the altitude at Kototabang $(865 \mathrm{~m}$ MSL).

as described in the previous subsection). Days with missing rawinsonde data were omitted. As shown in Fig. 7 for the case of cloud systems migrating westward, zonal wind anomalies below $4.0 \mathrm{~km}$ at Kototabang were opposite signs at $10-12 \mathrm{~km}$, where temperature was near the threshold value of $230 \mathrm{~K}$ at 0030, 0630, and 1830 LST. Such wind directions at 0030 and 1830 were consistent with lower-tropospheric convergence and upper-tropospheric divergence in cloud systems migrating westward. In contrast, a clear relationship between wind direction and cloud position was not observed in the eastern side of Kototabang (Jambi). Similar structures were found at both stations for cases
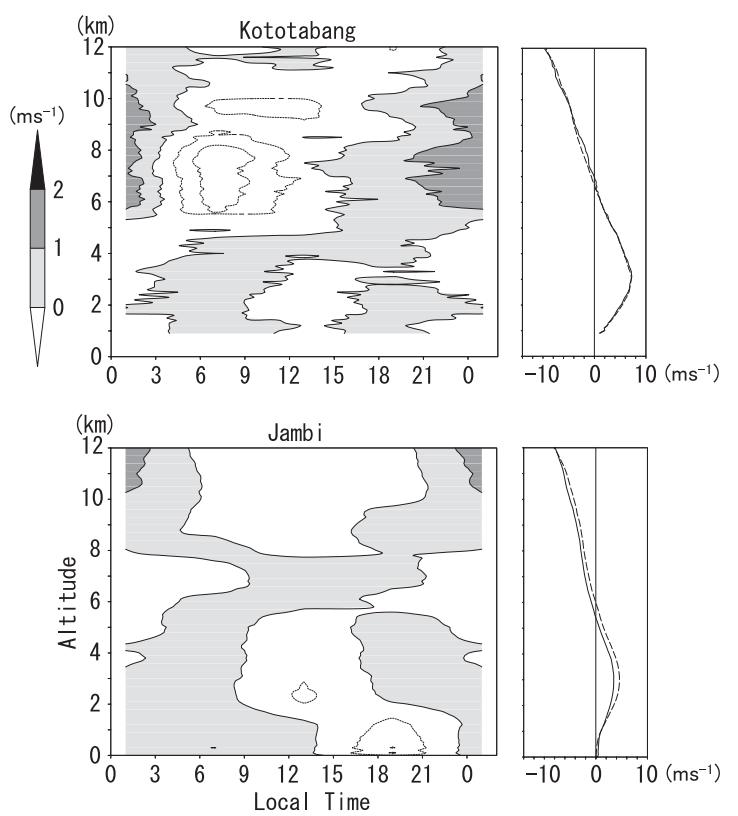

Fig. 7. Vertical-local time cross-sections of zonal wind anomalies for cases when cloud systems migrated westward (left panels) and mean vertical profiles of zonal wind (right panels) at Kototabang (upper panels) and Jambi (lower panels) in November 2001. The contour interval in the left panels is $1 \mathrm{~ms}^{-1}$, and broken lines indicate easterly winds. Profiles show zonal wind (solid line) averaged for days of westward cloud system migration and the monthly mean zonal wind (broken line).

of westward and eastward migrations (not shown).

\section{Statistical analysis of May 2001-April 2002}

\subsection{Seasonal variations of migratory directions of cloud systems}

The cross-section analysis in Fig. 4 was used to determine cloud system migration between May 2001 and April 2002. Figure 8 shows timelongitude cross-sections of $\alpha$ along $\mathrm{CC}^{\prime}$ (approximately along the center of Sumatera Island) from May 2001 to April 2002. Both westward and eastward migrations occurred in May and June, and $\alpha$ for both directions decreased in June. Only westward propagation occurred in July, when $\alpha$ was small. Westward and east- 

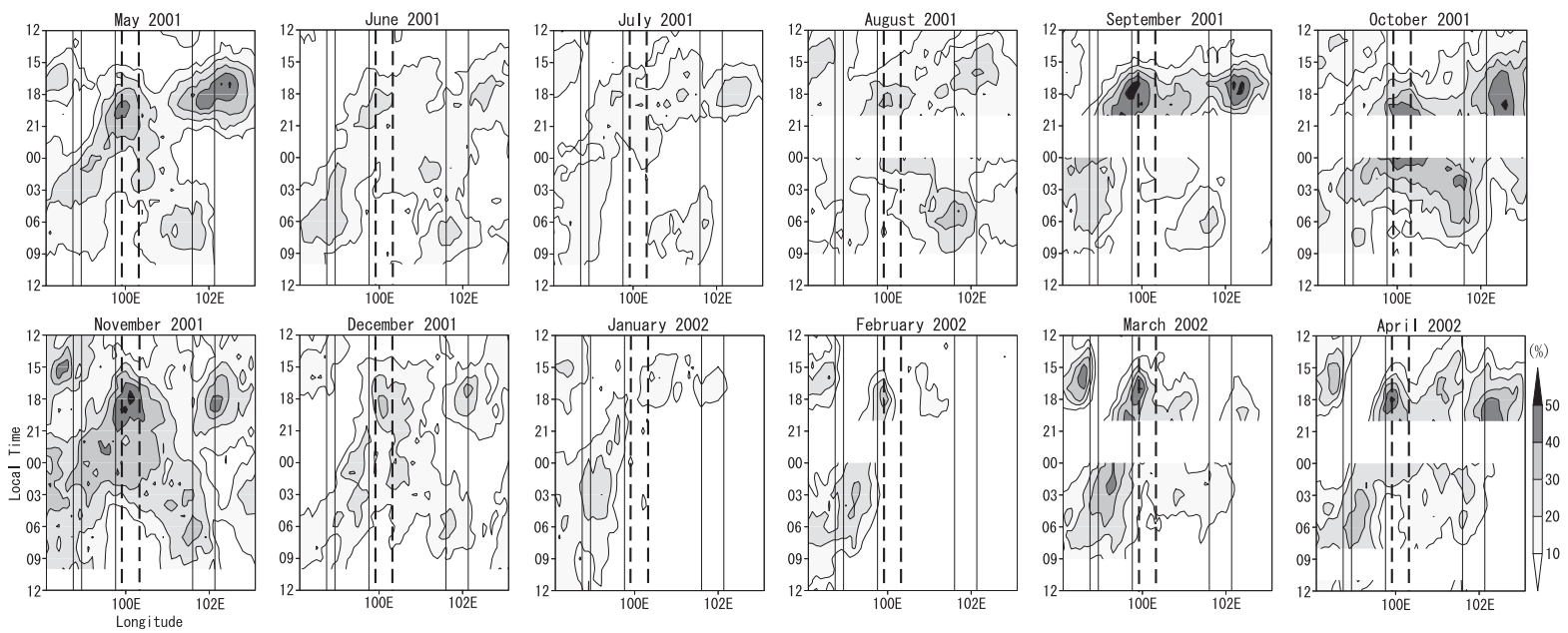

Fig. 8. As in Fig. 4 but for a cross-section CC' $^{\prime}$ every month from May 2001-April 2002.

Table 2. Seasonal-“meridional” distributions of westward and eastward migration occurrences (see text for definitions) of deep cloud systems (cloud-top temperature $\leq 230 \mathrm{~K}$ ) for May 2001-April 2002.

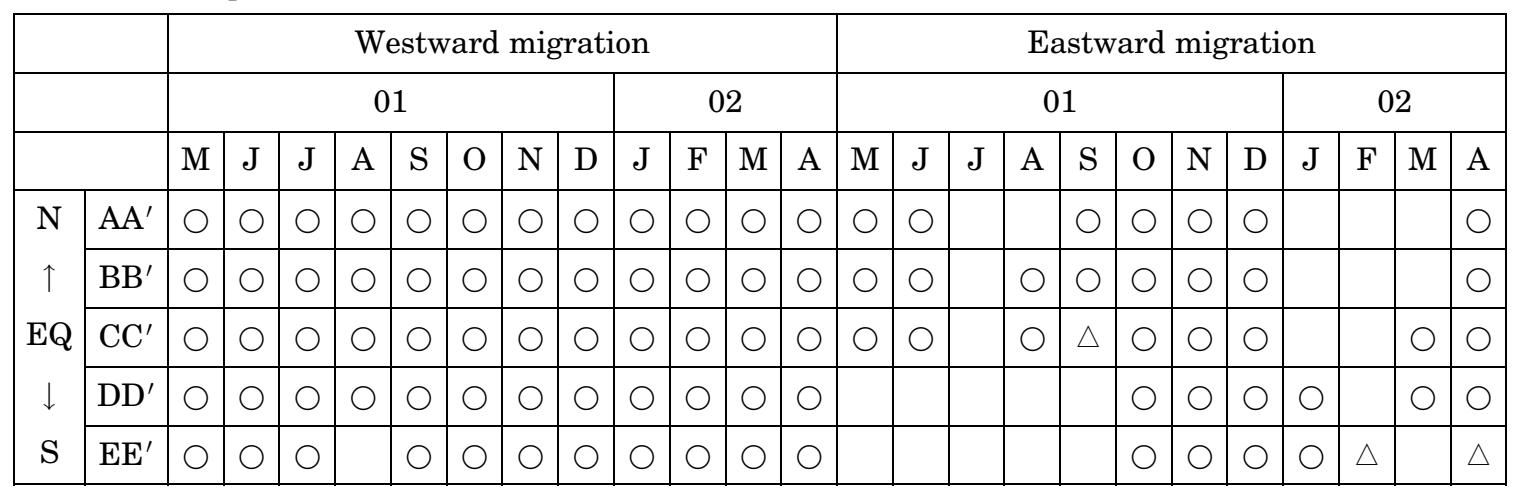

ward migrations occurred in August and September, but cloud systems did not reach the eastern coast in September. Westward migration dominated in September, and $\alpha$ was larger in September than in August. Migration in October, November, and December was both westward and eastward; $\alpha$ was largest in November. From January to March, westward migration occurred as $\alpha$ increased. Migration in both directions occurred in March and April.

Seasonal variations of occurrence of cloud system migration over the whole of Sumatera Island were investigated, applying the same procedure as mentioned above for $\mathrm{CC}^{\prime}$ (Table 2). At $\mathrm{CC}^{\prime}, \mathrm{DD}^{\prime}$, and $\mathrm{EE}^{\prime}$, cross-sections in which distances between the mountains and the east- ern coast are larger than along $\mathrm{AA}^{\prime}$ and $\mathrm{BB}^{\prime}$, cloud systems did not reach the eastern coast when they migrated eastward from the mountainous area in September 2001, and February and April 2002 (marked with $\triangle$ in Table 2).

Westward migration appeared in almost all cross-sections and seasons, except for $\mathrm{EE}^{\prime}$ in August. Clouds that grew to levels with temperature cooler than $230 \mathrm{~K}$ were rarely observed in July and August along $\mathrm{EE}^{\prime}$. Eastward migration, in contrast, seasonally varied. Eastward migration appeared over northern Sumatera Island in May and June, but did not appear in July. Eastward migration reappeared over northern Sumatera Island in August and September. It extended to the south in October 
through December, and persisted over southern Sumatera Island in January and February before extending northward in March. The region of eastward migration oscillated around the Equator with an annual cycle, shifting toward the summer hemisphere near the solstice.

\subsection{Comparison with large-scale features}

The ITCZ also shows an annual cycle, oscillating northward and southward around the Indonesian maritime continent (see, e.g., Murakami and Matsumoto 1994; Okamoto et al. 2003). The ITCZ is sometimes not clearly defined over Indonesia, but the ITCZ location nevertheless could be defined around $100^{\circ} \mathrm{E}$ from May 2001 to April 2002 (see subsection 2.1.a) as shown in Fig. 9(a).

The ITCZ shifted northward during May, June, and July. In July the center of the ITCZ was located near $20^{\circ} \mathrm{N}$ (northern Thailand). The summer monsoon peaked over Southeast Asian in mid-July. After July, the ITCZ began to shift southward. The ITCZ covered all of Sumatera Island in November, and $\alpha$ was especially high during this month. The ITCZ subsequently continued southward, reaching $10^{\circ} \mathrm{S}$ in January and February. The ITCZ moved northward again from March to April as its center passed over the Equator. The annual cycle ITCZ motion resembled the annual cycle of the area of eastward migrating cloud systems shown in Table 2.

Because some previous studies (Asai et al. 1998; Satomura 2000; Okumura et al. 2003; Mori et al. 2004) noted a relationship between cloud system migration and background wind, wind directions in the ITCZ are shown (Fig. 9). Westerly winds at $850 \mathrm{hPa}$ were at a maximum from May through August around $10^{\circ} \mathrm{N}$, where cloud amounts associated with the ITCZ were also large. This zonal wind structure shifted southward from September to December. Westerly winds at $850 \mathrm{hPa}$ nearly vanished between late December and January, when the cloud amounts were smallest. After February, wind structures associated with the ITCZ returned northward. In contrast, upper-tropospheric easterly winds area covered the ITCZ and Sumatera Island throughout the analysis period.

The movements of zonal wind structures and of the ITCZ during the period analyzed here were similar to climatological features of the
ITCZ revealed by outgoing long-wave radiation (OLR) data, derived from NOAA data for a different period by Murakami and Matsumoto (1994), and by operational rawinsonde data provided by Okamoto et al. (2003). Therefore, the behavior of the ITCZ in this study's observation period was not abnormal, indicating that the diurnal cycle of cloud activities, noted in this paper, likely appears every year.

\section{Discussions}

\subsection{Relationships between water vapor, cloud, and rainfall variations}

This subsection compares cloud system features over Sumatera throughout one year as described in the present study with results from earlier studies that focused on water vapor and rainfall features with more limited spatial and temporal dimensions.

Automatic raingauge measurements (cf., Hamada 2003) for four years (1999-2002) at Kototabang showed that diurnal rainfall peaked between 15-17 LST in both rainy seasons (March-May and September-November) and around 18 LST in both "dry" (more accurately, minimum rainfall) seasons (June and January). Renggono et al. (2001) used profiler radar echo observations at Kototabang, and showed a peak in convective rainfall around 14 LST and a peak in stratiform rainfall around 18 LST. Wu et al. (2003) showed maximum precipitable water observed by GPS at Kototabang in the late afternoon (around 17 LST) in the dry season (August 2001), and speculated that water vapor could be converged over the mountainous area by a thermally induced local circulation. That study used observations only at one station and during a limited period in the dry season (August 2001); similar processes may work in other seasons in other areas over other parts of western Sumatera Island. Thus, deep cloud systems generated at 15-18 LST over mountainous areas (see Fig. 3) created the afternoon-evening rainfall peaks observed at Kototabang. Rains resulted from deep convective clouds associated with earlier local circulation (around 15 LST) and from stratiform clouds below high anvils at later times (around 18 LST).

Cloud systems responsible for a local rainfall peak in mountainous area moved during the night as shown in this paper. Mori et al. (2004) 
(a)

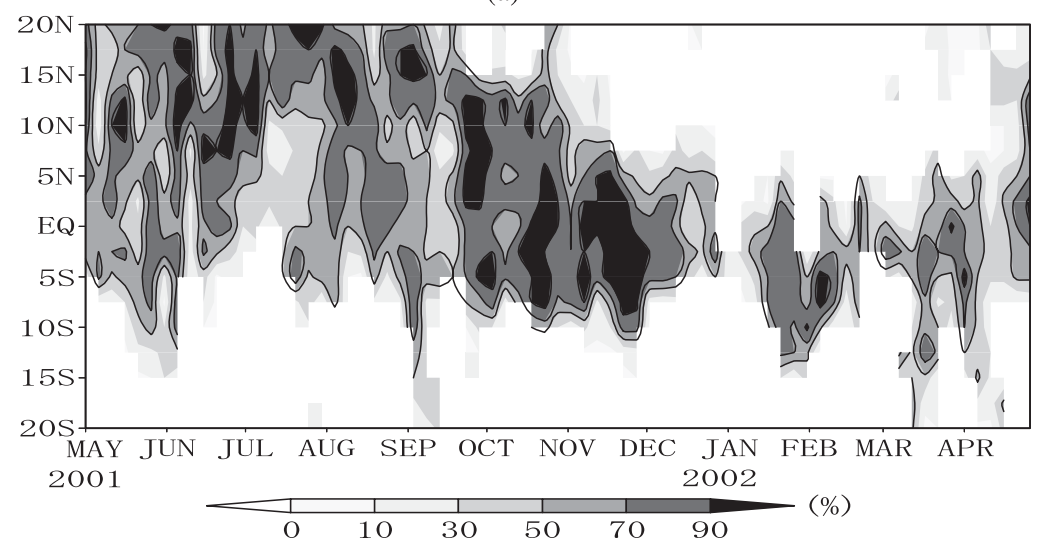

(b)

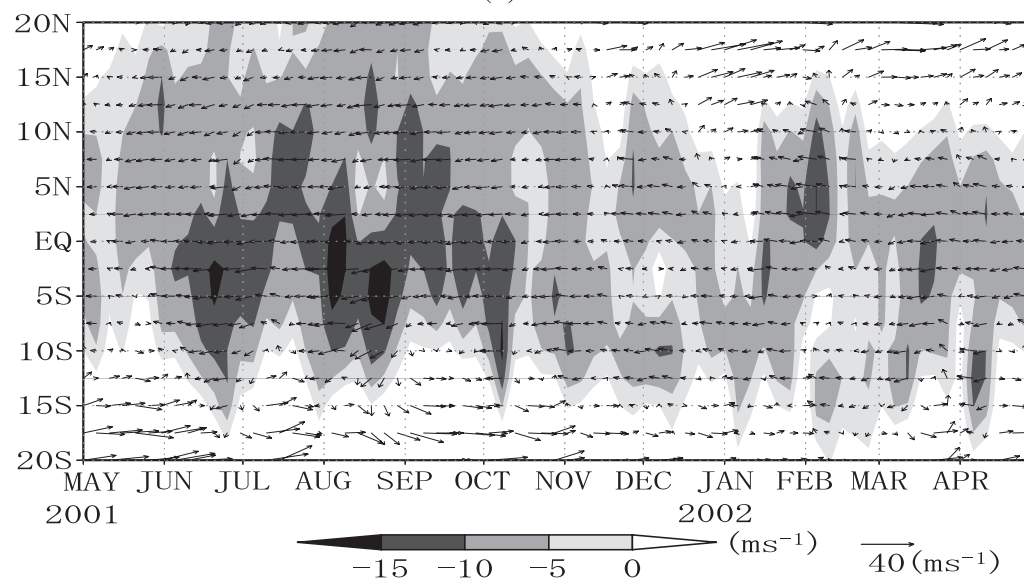

(c)

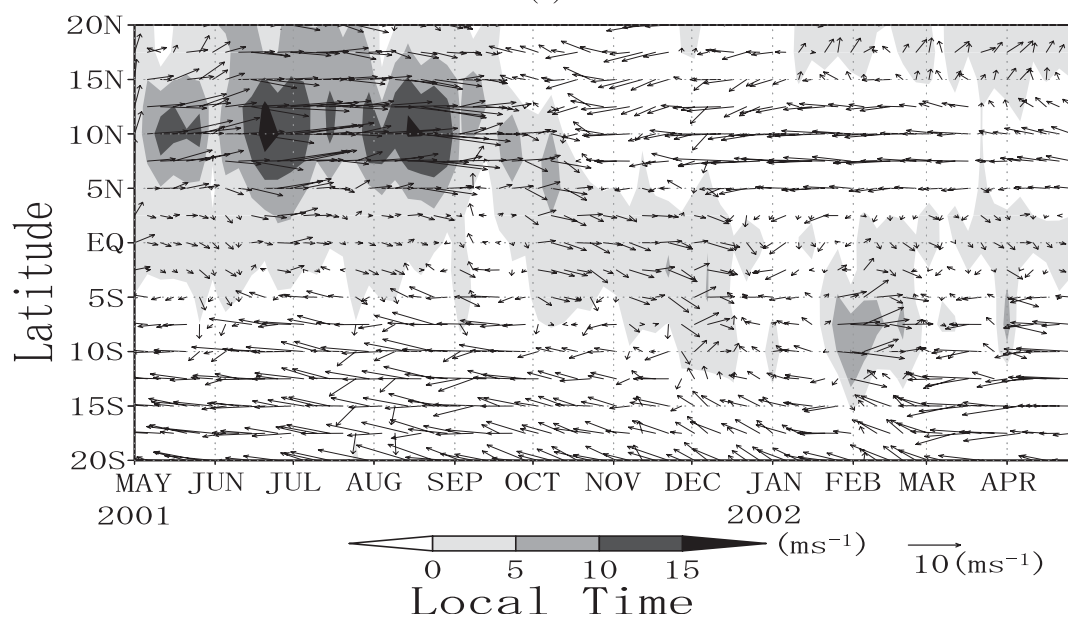

Fig. 9. Latitude-time cross-sections (around $100^{\circ} \mathrm{E}$, spatial width is $2.5^{\circ}$ from May 2001-April 2002) of (a) $\alpha$ of cloud systems (cloud-top temperature is between 170 and $270 \mathrm{~K}$; see Subsection 2.1.a), and (b) 300- and (c) 850-hPa horizontal wind (arrows: upward is northward; shaded represents easterly in (b) and westerly in (c)) derived from the NCEP/NCAR objective reanalysis. 
used discontinuous TRMM space-borne radar data collected for three years over central Sumatera including Kototabang, and showed a peak in rainfall migration (Fig. 5 of their paper) that was roughly consistent with results in the present study for deep cloud system migration (see the cross-section panels in Fig. 8). Therefore, the migrating cloud system studied in this paper mainly makes local rainfall peaks at many places over Sumatera Island.

\subsection{Conditions of cloud system migrations}

As shown in subsections 3.1 and 4.1, westward and eastward cloud system migrations occurred with different frequencies at different places (cross-sections) and during different seasons. Westward migration appeared in almost all seasons and areas; eastward migration seasonally varied following the north-south displacement of the ITCZ.

Some previous studies (Asai et al. 1998; Satomura 2000; Okumura et al. 2003; Mori et al. 2004) suggested a relationship between cloud/ precipitation system migration and background wind. Easterly winds dominated throughout the year in the upper troposphere at $100^{\circ} \mathrm{E}$ [Fig. 9(b)], and westward cloud migration occurred in almost all months except August 2001 over southern Sumatera Island $\left(\mathrm{EE}^{\prime}\right)$. However, the eastward migration of the cloud systems could not be related to the background wind, because the upper-tropospheric easterlies were counter to the eastward migration, though the dominant lower-tropospheric wind was westerly [Fig. 9(c)] when eastward migration occurred.

Annual-mean background, lower-tropospheric zonal wind is westerly, but the actual wind shows seasonal and meridional variations. The cross-equatorial monsoon circulation near Sumatera Island is southeasterly (northwesterly) in the southern hemisphere side and southwesterly (northeasterly) in the northern hemisphere side in the northern summer (winter) season (Murakami and Matsumoto 1994; Okamoto et al. 2003). This circulation converges into the ITCZ that is in the northern (southern) hemisphere during northern (southern) summer. Thus, westerly wind occurred in the ITCZ, and eastward movement of super cloud clusters appears frequently (Nakazawa 1988). Such super cloud clusters had an intra- seasonal temporal scale and included smallerscale clusters that moved mainly westward over the Pacific. However, super cloud clusters did not have clear zonal propagation over Sumatera (Nitta et al. 1992). Figure 2 shows that in November 2001, cloud systems generated with a diurnal cycle over the mountains of Sumatera moved eastward when super cloud clusters moved eastward from the Indian Ocean and passed over Sumatera Island. These are the eastward migration cases discussed in this paper. Lower-tropospheric background westerly winds, and cloud disturbances that moved from the Indian Ocean along the ITCZ were related to eastward cloud migration over Sumatera.

\section{Conclusions}

This paper has described systematic cloud migration with a diurnal cycle over Sumatera, an island with a northwest-southeast length of $1,500 \mathrm{~km}$. Analyses were based on GMS IR1 data, and frequent observations with rawinsondes and a wind profiler. Cloud systems developed and grew to $11 \mathrm{~km}$ over the mountains of western Sumatera Island in the afternoon, and migrated for distances of several hundreds of kilometers both westward and eastward from night to morning.

Climatological analysis for one year (May 2001-April 2002) showed that westward migration, with a diurnal cycle, appeared in almost all months and over almost all of western Sumatera, except for in August over southern Sumatera Island. Eastward migration with a diurnal cycle was observed only in a zone that shifted northward and southward in an annual cycle. The zone where the eastward migration appeared approximately overlapped the ITCZ; thus, eastward migration was likely related to the ITCZ. Westerly winds in the lower troposphere dominated, and super cloud clusters moved eastward in the ITCZ around $100^{\circ} \mathrm{E}$.

The existence of diurnal cycle in systematic cloud generation and migration over Sumatera Island must be quite important to consider the behavior of super clusters or intraseasonal variations in this region, as suggested by Nitta et al. (1992) and Nitta and Sekine (1994). Such phenomena, with horizontal scales exceeding $1,000 \mathrm{~km}$ and temporal scales of one day or shorter, are difficult to simulate in present-day 
general circulation models and to understand with dynamical theories. Intense observations will continue over Sumatera, using instruments discussed in Murata et al. (2002), Wu et al. (2003), and Mori et al. (2004).

\section{Acknowledgments}

We heartily thank colleagues of BPPT, BMG, and LAPAN in the Indonesian side, and Kyoto University, Kobe University, and JAMSTEC in the Japanese side for their strong collaborations in observations. We thank Prof. T. Yasunari of Nagoya University, Dr. T. Satomura of Kyoto University, and Prof. S. Fukao and Dr. N. Kawano of RISH, Kyoto University for their useful suggestions, comments, and encouragement. The EAR belongs to RISH of Kyoto University, Japan, and is operated by RISH and LAPAN, Indonesia based upon the agreement between RISH and LAPAN signed on September 8, 2000. We are grateful to Prof. Richard H. Johnson, Dr. Brian E. Mapes, and Dr. Yoshiaki Shibagaki for reading the manuscript carefully and helpful comments. Thanks are also extended to the constructive comments of the Editor (Prof. Y. Fujiyoshi) and two anonymous reviewers who greatly improved the content of this manuscript. GMS IR1 data were observed by Japan Meteorological Agency (JMA) and distributed by Kochi University, Japan. Most of the figures were drawn using GrADS, a free software developed by Brian E. Doty, Center for Ocean-Land-Atmosphere interaction, Department of Meteorology, University of Maryland. Generic Mapping Tools (GMT) were used for drawing the map.

\section{References}

Asai, T., S. Ke, and Y. Kodama, 1998: Diurnal variability of cloudiness over East Asia and the western Pacific Ocean as revealed by GMS during the warm season. J. Meteor. Soc. Japan, 76, 675-684.

Carbone, R.E., J.D. Tuttle, D.A. Arijevych, and S.B. Trier, 2002: Inferences of predictability associated with warm precipitation episodes. $J$. Atmos. Sci., 59, 2033-2056.

Chen, S. and R.A. Houze, 1997: Diurnal variation and life-cycle of deep convective systems over the tropical Pacific warm pool. Quart. J. Roy. Meteor. Soc., 123, 357-388.

Fukao, S., H. Hashiguchi, M. Yamamoto, T. Tsuda, T. Nakamura, M.K. Yamamoto, T. Sato, M.
Hagio, and Y. Yabugaki, 2003: Equatorial atmosphere radar (EAR): System description and first results. Radio Sci., 38, 3, 1053, doi:10.1029/2002RS002767.

Hadi, T.W., T. Tsuda, H. Hashiguchi, and S. Fukao, 2000: A Tropical sea-breeze circulation and related atmospheric phenomena observed with $L$-band boundary layer radar in Indonesia. $J$. Meteor. Soc. Japan, 78, 123-140.

, T. Horinouchi, T. Tsuda, H. Hashiguchi, and S. Fukao, 2002: Sea-breeze circulation over Jakarta, Indonesia: A climatology based on boundary layer radar observations. Mon. Wea. Rev., 130, 2153-2166.

Hamada, J.-I., M.D. Yamanaka, J. Matsumoto, S. Fukao, P.A. Winarso, and T. Sribimawati, 2002: Spatial and temporal variations of the rainy season over Indonesia and their link to Enso. J. Meteor. Soc. Japan, 80, 285-310.

— 2003: A climatological study on rainfall variations over the Indonesian maritime continent, Doctoral thesis, Graduate School of Science, Kyoto University, 189 pp.

Hashiguchi, H., S. Fukao, M.D. Yamanaka, T. Tsuda, S.W.B. Harijono, and H. Wiryosumarto, 1995: Boundary layer radar observations of the passage of the convection center over Serpong, Indonesia during the TOGA COARE intensive observation period. J. Meteor. Soc. Japan, 73, $535-548$.

— — - T. Tsuda, M.D. Yamanaka, S.W.B. Harijono, and H. Wiryosumarto, 1996: An overview of the planetary boundary layer observations over equatorial Indonesia with an L-band clear-air Doppler radar. Beitr. Phys. Atomosel., 69, 13-25.

Hendon, H.H. and K. Woodberry, 1993: The diurnal cycle of tropical convection. J. Geophys. Res., 98, 16623-16637.

Houze, R.A., S.G. Geotis, F.D. Markes, and A.K. West, 1981: Winter monsoon convection in the vicinity of north Borneo. Part I: Structure and time variation of the clouds and precipitation. Mon. Wea. Rev., 109, 1595-1614.

Janowiak, J.E., P.A. Arkin, and M. Morrissey, 1994: An examination of the diurnal cycle in oceanic tropical rainfall using satellite and in situ data. Mon. Wea. Rev., 122, 2296-2311.

Johnson, R.H. and D.C. Kriete, 1982: Thermodynamic and circulation characteristics of winter monsoon tropical mesoscale convection. Mon. Wea. Rev., 110, 1898-1911.

Liberti, G.L., F. Cheruy, and M. Desbois, 2001: Land effect on the diurnal cycle of clouds over the TOGA COARE area, as observed from GMS IT data. Mon. Wea. Rev., 129, 1500-1517.

Mapes, B.E., T.T. Warner, M. Xu, and A.J. Negri, 
2003: Diurnal patterns of rainfall in northwestern South America. Part I: Observations and context. Mon. Wea. Rev., 131, 799-812.

, —, and M. Xu, 2003: Diurnal patterns of rainfall in northwestern South America. Part III: Diurnal gravity waves and nocturnal convection offshore. Mon. Wea. Rev., 131, 830844.

Meisner, B.N. and P.A. Arkin, 1987: Spatial and annual variations in the diurnal cycle of largescale tropical convective cloudiness and precipitation. Mon. Wea. Rev., 115, 2009-2032.

Minnis, P. and E.F. Harrison, 1984: Diurnal variability of regional cloud and clear-sky radiative parameters derived from GOES Data. Part II: November 1978 cloud distributions. J. Appl. Meteor., 23, 1012-1031.

Mori, S., J.-I. Hamada, Y.I. Tauhid, M.D. Yamanaka, N. Okamoto, F. Murata, N. Sakurai, H. Hashiguchi, and T. Sribimawati, 2004: Diurnal land-sea rainfall peak migration over Sumatera Island, Indonesian maritime continent, observed by TRMM satellite and intensive rawinsonde soundings. Mon. Wea. Rev., 132, 2021-2039.

Murakami, M., 1983: Analysis of the deep convective activity over the western Pacific and Southeast Asia. Part I. J. Meteor. Soc. Japan, 61, 60-76.

Murakami, T. and J. Matsumoto, 1994: Summer monsoon over the Asian Continent and western North Pacific. J. Meteor. Soc. Japan, 72 , $719-745$.

Murata, F., M.D. Yamanaka, M. Fujiwara, S.-Y. Ogino, H. Hasiguchi, S. Fukao, M. Kudsy, T. Sribimawati, S.W.B. Harijono, and E. Kelana, 2002: Relationship between wind and precipitation observed with a UHF radar, GPS rawinsondes and surface meteorological instruments at Kototabang, west Sumatera during September-October 1998. J. Meteor. Soc. Japan, 80, 347-360.

Nakazawa, T., 1988: Tropical super clusters within Intraseasonal variations over the western $\mathrm{Pa}$ cific. J. Meteor. Soc. Japan, 66, 823-839.

Nitta, T., T. Mizuno, and K. Takahashi, 1992: Multiscale convective systems during the initial phase of the 1986/87 El Niño. J. Meteor. Soc. Japan, 70, 447-466.

and S. Sekine, 1994: Diurnal variation of convective activity over the tropical western Pacific. J. Meteor. Soc. Japan, 72, 627-641.

Ohsawa, T., H. Ueda, T. Hayashi, A. Watanabe, and J. Matsumoto, 2001: Diurnal variations of con- vective activity and rainfall in tropical Asia. $J$. Meteor. Soc. Japan, 79, 333-352.

Okamoto, N., M.D. Yamanaka, S.-Y. Ogino, H. Hashiguchi, N. Nishi, T. Sribimawati, and A. Numaguti, 2003: Seasonal variations of tropospheric wind over Indonesia: Comparison between collected operational rawinsonde data and NCEP reanalysis for 1992-99. J. Meteor. Soc. Japan, 81, 829-850.

Okumura, K., T. Satomura, T. Oki, and W. Khantiyanan, 2003: Diurnal variation of precipitation by moving mesoscale systems: Radar observations in northern Thailand. Geophys. Res. Lett., 30(20), 10.1029/2003GL018302.

Ramage, C.S., 1968: Role of a tropical "maritime continent" in the atmospheric circulation. Mon. Wea. Rev., 96, 365-369.

Renggono, F., H. Hashiguchi, S. Fukao, M.D. Yamanaka, S.-Y. Ogino, N. Okamoto, F. Murata, B.P. Sitorus, M. Kudsy, M. Kartasasmita, and G. Ibrahim, 2001: Precipitating clouds observed by $1.3-\mathrm{GHz}$ boundary layer radars in equatorial Indonesia. Ann. Geophys., 19, 889897.

Riley, G.T., M.G. Landin, and L.F. Bosart, 1987: The diurnal variability of precipitation across the central Rockies and adjacent Great Plains. Mon. Wea. Rev., 115, 1161-1172.

Sakagami, F.R. Ohgushi, and D.W. Roubik, 1990: Natural History of Social Wasps and Bees in Equatorial Sumatra, Hokkaido University Press, Sapporo, Japan, 274pp.

Satomura, T., 2000: Diurnal variation of precipitation over the Indo-China Peninsula: Twodimensional numerical simulation. J. Meteor. Soc. Japan, 78, 461-475.

Wallace, J.M., 1975: Diurnal variations in precipitation and thunderstorm frequency over the conterminous United States. Mon. Wea. Rev., 103, 406-419.

Warner, T.T., B.E. Mapes, and M. Xu, 2003: Diurnal patterns of rainfall in northwestern South America. Part II: Model simulations. Mon. Wea. Rev., 131, 813-829.

Wu, P.-M., J.-I. Hamada, S. Mori, Y.I. Tauhid, M.D. Yamanaka, and F. Kimura, 2003: Diurnal variation of precipitable water over a mountainous area of Sumatra Island. J. Appl. Meteor., 42, 1107-1115.

Yang, G.-Y. and J. Slingo, 2001: The diurnal cycle in the Tropics. Mon. Wea. Rev., 129, 784-801.

Zuidema, P., 2003: Convective clouds over the Bay of Bengal. Mon. Wea. Rev., 131, 780-798. 